\title{
The Safe Concentration Determination for Public Health Problems Due to Inhalation of Air Containing Hydrogen Sulfide Around Industrial Area of Medan Indonesia
}

\author{
Erlinda Rasikhah Hadi Salma ${ }^{1}$, Abdul RohimTualeka' ${ }^{1}$, Pudji Rahmawati ${ }^{2}$, Syamsiar S Russeng ${ }^{3}$, Atjo Wahyu ${ }^{3}$ \\ ${ }^{1}$ Department of Occupational Health and Safety, Faculty of Public Health, Airlangga University, 60115 \\ Surabaya, East Java, Indonesia; ${ }^{2}$ Department of Development of Islamic Society, State Islamic University \\ Sunan Ampel, Surabaya, East Java, Indonesia; ${ }^{3}$ Department of Occupational Health and Safety, Faculty of \\ Public Health, Hasanuddin University, Makassar, East Java, Indonesia
}

\begin{abstract}
Hydrogen sulfide or $\mathrm{H}_{2} \mathrm{~S}$ was a chemical compound which is colorless, flammable, explosive, corrosive, dangerous, and poisonous with the smell like rotten eggs. The source of $\mathrm{H}_{2} \mathrm{~S}$ came from human activities namely industrial activity and waste. The animal feed industry and the seafood processing industry were industries that produced waste containing $\mathrm{H} 2 \mathrm{~S}$ gas. This research was done to determine the safe concentration of $\mathrm{H}_{2} \mathrm{~S}$ which had the potential to disrupt the health of the community around Medan industrial area. This was an observational research,cross sectional and descriptive. The research population was residential community around the industrial area of animal feed and seafood processing at a radius of $300 \mathrm{~m}$ and $800 \mathrm{~m}$. The number of research sample was 104 people. The data analysis used quantitative data analysis manually to decide the safe concentration ( $\mathrm{C}$ safe) of $\mathrm{H}_{2} \mathrm{~S}$ for community which were obtained from the data of experimental animal weight that was white mice(Wanimal),body surface area of white mice(BSA animal), workerweight(W), workerheight $(\mathrm{h})$, workerrespiratory rate (BR), body surface area of worker (BSA), length of working time(t), concentration of $\mathrm{H}_{2} \mathrm{~S}(\mathrm{C})$, NOAEL, animal $\mathrm{Km}$, human $\mathrm{Km}$, and safe human dose of toxin(SHD).
\end{abstract}

The results showed measurements of $\mathrm{H}_{2} \mathrm{~S}$ concentrations in the industrial area of animal feed and seafood processing at $300 \mathrm{~m}$ was $0.0022 \mathrm{ppm}$ while at $800 \mathrm{~m}$ was $0.0064 \mathrm{ppm}$, which means that both were above the Threshold Limit Value (TLV) of 0,0005 ppm according to the ATSDR provisions regarding the Odor TLV $\mathrm{H}_{2} \mathrm{~S}$. According to KepMenLH No.KEP-50/MENLH/1996 concerning standard level of odor with TLV of $0.02 \mathrm{ppm}$, then only for the community around industrial areas at radius $300 \mathrm{~m}$ with a concentration of $0.022 \mathrm{ppm}$ which was above the TLV. Akan tetapi konsentrasi hidrogen sulfida pada radius $300 \mathrm{~m}$ dan $800 \mathrm{~m}$ tersebut berada di bawah Minimal Risk Levels (MRL) tingkat pemaparan inhalasi hidrogen sulfida yang ditetapkan olehAgency for Toxic Substances and Disease Registry(ATSDR) 2016 untuk efek akut sebesar 0,07 ppm.\ Upaya pengendalian yang dilakukan untukmasyarakat berisikoadalahmengkonsumsi enzim sitokrom P450 yang terkandung dalam makanan yang mengandung zat besi seperti kacang-kacangan, sayuran, daging, kuning telur, dan ikan untuk menurunkan tingkat hidrogen sulfida dalam tubuh.Control efforts taken for people at risk were consuming the cytochrome P450 enzyme in iron-containing foods such as nuts, vegetables, meat, egg yolks, and fish to reduce the level of $\mathrm{H}_{2} \mathrm{~S}$ in the body. TSelain itu adanya gangguan pada enzim sitokrom oksidase menyebabkan suplai energy hasil oksidasi di mitokondria berkurang, untuk itu perlu mengkonsumsi makanan yang mengandung antioksidan seperti alpukat, delima dan anggur (Tualeka, 2013).The interference with the cytochrome oxidase enzyme caused the energy supply from

Corresponding Author:

Abdul Rohim Tualeka

Department of Occupational Health and Safety,

Public Health Faculty, Airlangga University,

Surabaya, East Java, Indonesia

Phone: +62 81333519732

Email: abdul-r-t@fkm.unair.ac.id oxidation in the mitochondria to decrease, so it is necessary to consume foods that contain antioxidants such as avocados, pomegranates and grapes (Tualeka, 2013).

Keywords: Hydrogen Sulfide, safe concentration, public, animal feed and seafood processing industries. 


\section{Introduction}

Yong Bai (2019) explains that $\mathrm{H}_{2} \mathrm{~S}$ is a colorless gas, flammable, poisonous, and has a smell like rotten eggs. ${ }^{(1)}$ Humans can smell hydrogen sulfide at low concentrations in the air, starting at $0,0005 \mathrm{ppm}$. This can increase the risk of exposure to air levels which can cause serious health effects. $\mathrm{H}_{2} \mathrm{~S}$ is mainly absorbed through the lungs, digestive tract and skin (ATSDR, 2016). ${ }^{(2)}$

$\mathrm{H}_{2} \mathrm{~S}$ inhibits the cytochrome oxidase enzyme that contains iron inside mitochondria as anenergy-producer. (3) Mitochondria are susceptible to oxidative stress which requires adequate antioxidants. The interference with the cytochrome oxidase enzyme causes the energy supply from oxidation in the mitochondria to decrease, called hypoxia(Tualeka, 2013). (Tualeka, 2013). ${ }^{(4)}$

ACGIH sets the Threshold Limit Value of $\mathrm{H}_{2} \mathrm{~S}$ is $10 \mathrm{ppm}^{(5)}$ In Indonesia according to KepMenLH No.KEP-50/MENLH/11/1996, the TLV is set at 0.02 ppm. ${ }^{(6)}$ Sedangkan berdasarkan Agency for Toxic Substances and Disease Registry (ATSDR) Nilai Ambang Batas (NAB) hidrogen sulfida sebesar 0,0005 ppm sesuai ketentuan ATSDR tentang Nilai Ambang Batas Bau Hidrogen Sulfida (H2S).Based on the ATSDR, the TLV of $\mathrm{H}_{2} \mathrm{~S}$ is $0,0005 \mathrm{ppm}$ in accordance with ATSDR provisions regarding the odor TLV of $\mathrm{H}_{2} \mathrm{~S}{ }^{(2)}$

In Dipa study (2016), the results of measurements of the $\mathrm{H}_{2} \mathrm{~S}$ concentrationdi in kawasan industri pakan ternak dan pengolahan hasil laut radius $300 \mathrm{~m}$ sebesar $0,03 \mathrm{mg} /$ $\mathrm{m}^{3}(0,0022 \mathrm{ppm})$ sedangkan konsentrasi $\mathrm{H}_{2} \mathrm{~S}$ pada radius $800 \mathrm{~m}$ sebesar $0,009 \mathrm{mg} / \mathrm{m}^{3}(0,0064 \mathrm{ppm})$, yang berarti keduanya berada di atas Nilai Ambang Batas (NAB) sebesar 0,0005 ppm sesuai ketentuan ATSDR tentang Nilai Ambang Batas Bau Hidrogen Sulfida $\left(\mathrm{H}_{2} \mathrm{~S}\right)$.industrial areas at $300 \mathrm{~m}$ is $0.0022 \mathrm{ppm}$ while the concentration of $\mathrm{H}_{2} \mathrm{~S}$ at $800 \mathrm{~m}$ is $0.0064 \mathrm{ppm} .{ }^{(7)} \mathrm{It}$ means both are above the TLV of $0,0005 \mathrm{ppm}$ according to the ATSDR provisions regarding the odor TLV of $\mathrm{H}_{2} \mathrm{~S}$. Sedangkan menurut KepMenLH No.KEP-50/ MENLH/1996 tentang baku tingkat kebauan dengan Nilai Ambang Batas (NAB) sebesar 0,02 ppm maka hanya pada masyarakat kawasan industri pakan ternak dan pengolahan hasil laut (radius $300 \mathrm{~m}$ ) dengan konsentrasi sebesar 0,022 ppm yang berada di atas Nilai Ambang Batas (NAB).According to KepMenLH No.KEP-50/MENLH/1996 concerning standard level of odor with TLV is $0.02 \mathrm{ppm}$, then only for the community around industrial areas at $300 \mathrm{~m}$ with a concentration of $0.022 \mathrm{ppm}$ is above the TLV. Berdasarkan penelitian yang dilakukan tidak menimbulkan efek karsinogenik, namun berdampak pada kesehatan jika terpapar secara kontinyu.

Research in Norway regarding the assessment of exposure $\mathrm{H}_{2} \mathrm{~S}$ in wastewater treatment workers has shown that 93 workers are above the safe limit of the $\mathrm{H}_{2} \mathrm{~S}$ concentration which is $0,1 \mathrm{ppm}$. It can be concluded that the majority of wastewater treatment workers experience respiratory problem. ${ }^{(8)}$

Based on previous research on $\mathrm{H}_{2} \mathrm{~S}$ there has been no research on $\mathrm{H}_{2} \mathrm{~S}$ safe concentrations. The concentration of $\mathrm{H}_{2} \mathrm{~S}$ should be within safe limits so that it does not cause health problems for the community. Oleh karena itu, berdasarkan penjelasan di atas, penulis akan mengukur batasan konsentrasi aman hidrogen sulfida di pemukiman penduduk sekitar industri pakan ternak dan pengolahan hasil laut. Therefore, the author will measure the limits of the $\mathrm{H}_{2} \mathrm{~S}$ safe concentration in residential area around Medan industrial area.

\section{Material and Method}

This study was an observational, cross sectional and descriptive study.Populasi dalam penelitian ini adalah ibu rumah tangga yang tinggal di sekitar kawasan industri pada Radius $300 \mathrm{~m}$ dan radius $800 \mathrm{~m}$. The number of samples in this study were 52 people at a radius of $300 \mathrm{~m}$ and $800 \mathrm{~m}$, so the total sample was 104 people.

Data mengenai konsentrasi benzena di udara didapatkan dengan melakukan pengukuran langsung menggunakan alat ukur Spektrofotometer dan dianalisis dengan Ion sulfida bereaksi dengan p-amino-dimetil anilin dan $\mathrm{FeCl} 3$ membentuk metilen biru, mengacu pada metode SNI 19-7119.7-2005. The direct measurement of $\mathrm{H}_{2} \mathrm{~S}$ concentration used a spectrophotometer and analyzed with sulfide ions reacting with p-aminodimethyl aniline and $\mathrm{FeCl} 3$ forming methylene blue, referring to the SNI 19-7119.7-2005 method.

The research variables were $\mathrm{H}_{2} \mathrm{~S}$ concentrations, housewife weight, height, respiration rate, length of work day, body surface area, weight and body surface of white mice, the highest dose of toxin without effect on experimental animals (NOAEL), Animal Km, Human $\mathrm{Km}$, safe limit of dose (SHD), and $\mathrm{H}_{2} \mathrm{~S}$ concentration. 
The data analysis in this study was done by using quantitative data analysis manually to determine the $\mathrm{H}_{2} \mathrm{~S}$ safe concentrations.

\section{Results}

A. Characteristics of Animals and the Surface Area of Experimental Animals (White Mice): Suatu senyawa dikatakan toksik ketika masuk ke dalam tubuh dan berpotensi menyebabkan gangguan kesehatan tubuh.Pada umumnya, respon manusia terhadap toksikan secara kualitatif memiliki kesamaan dengan respon hewan yaitu sekitar 90\% gen hewan ini mirip dengan manusia, sehingga fakta ini menjadi dasar ekstrapolasi dari data hewan ke manusia.In general, the human response to toxicity qualitatively had similarities with the response of animals that was about $90 \%$ of the genes of these animals were similar to humans.

Table 1: Characteristics Distribution of Experimental Animals

\begin{tabular}{|c|c|c|}
\hline $\begin{array}{c}\text { Experimental Animals } \\
\text { (Tikus Putih) (White rat) }\end{array}$ & W (kg) & BSA (m2) \\
\hline 1 & 0,1405 & 0,024165 \\
\hline 2 & 0,1405 & 0,024165 \\
\hline 3 & 0,1410 & 0,024223 \\
\hline 4 & 0,1410 & 0,024223 \\
\hline 5 & 0,1395 & 0,024050 \\
\hline 6 & 0,1415 & 0,024165 \\
\hline
\end{tabular}

Based on the data of white rat body weight, the body surface of mice could be calculated using the following formula:

Animal BSA $=0,09 \mathrm{~W}^{0,67}$

B. Community Characteristics, Community Body Surface Area and Community Respiratory Rate: Based on Table 2, it was known that the average body weight at a $300 \mathrm{~m}$ and $800 \mathrm{~m}$ was 68 kg.Lama waktu penduduk khususnya ibu rumah tangga yang terpapar gas $\mathrm{H}_{2} \mathrm{~S}$ pada radius 300 $\mathrm{m}$ dalam sehari adalah 18 jam sedangkan lama waktu ibu rumah yang terpapar gas H2S pada radius $800 \mathrm{~m}$ dalam sehari adalah $15 \mathrm{jam}$. The length of time residents, especially housewives who were exposed to $\mathrm{H}_{2} \mathrm{~S}$ gas at $300 \mathrm{~m}$ in a day was 18 hours while at $800 \mathrm{~m}$ in a day was 15 hours. Tinggi badan menggunakan nilai rata-rata tinggi badan wanita dewasa Indonesia yaitu 153 $\mathrm{cm}$. Height used the average value of Indonesian adult women's height was $153 \mathrm{~cm}$.

Based on this data, the body surface area and the respiration rate of workers could be calculated using the following formula.

\section{Body Surface Rate}

$$
\mathrm{BSA}=\sqrt{\frac{\mathrm{W} \times h}{3600}}
$$

\section{Respiratory Rate}

$$
\mathrm{BR}=\frac{5,3 \times \ln \mathrm{W}-6,9}{24}
$$

\section{Information:}

BSABSA: Body Surface Area $\left(\mathrm{m}^{2}\right)$ : Body Surface Area $\left(\mathrm{m}^{2}\right)$

WW: Weight $(\mathrm{kg})$

$\mathrm{H}$ h: Height $(\mathrm{cm})$

BR: Breathing Rate (m/hour)

Table 2: Characteristics Distribution of Community, Body Surface Area of Community and Respiratory Rate of Community Around Medan Industrial Areas

\begin{tabular}{|c|c|c|c|c|c|}
\hline \multicolumn{6}{|c|}{ Radius 300 m } \\
\hline Population & $\mathbf{W}(\mathbf{K g})$ & $\begin{array}{c}\mathbf{h} \\
(\mathbf{C m})\end{array}$ & $\begin{array}{l}\text { BSA } \\
(\mathrm{m} 2)\end{array}$ & $\begin{array}{c}\text { t } \\
\text { (hour/ } \\
\text { day) }\end{array}$ & $\begin{array}{c}\text { BR } \\
\text { (m3/ } \\
\text { hour) }\end{array}$ \\
\hline 1 & 65 & 153 & 1,66 & 14 & 0,63 \\
\hline 2 & 76 & 153 & 1,8 & 16 & 0,67 \\
\hline 3 & 63 & 153 & 1,64 & 17 & 0,62 \\
\hline \multicolumn{6}{|l|}{ Etc. } \\
\hline 52 & 78 & 153 & 1,82 & 18 & 0,67 \\
\hline Average & 68 & 153 & 1,7 & 16,87 & 0,64 \\
\hline \multicolumn{6}{|c|}{ Radius 800 m } \\
\hline Population & $\begin{array}{c}\mathrm{W} \\
(\mathrm{Kg})\end{array}$ & $\begin{array}{c}\mathrm{h} \\
(\mathrm{Cm})\end{array}$ & $\begin{array}{l}\text { BSA } \\
\text { (m2) }\end{array}$ & $\begin{array}{c}\mathrm{t} \\
\text { (hour/ } \\
\text { day) }\end{array}$ & $\begin{array}{c}\text { BR } \\
\text { (m3/ } \\
\text { hour) }\end{array}$ \\
\hline 1 & 65 & 153 & 1,66 & 15 & 0,63 \\
\hline 2 & 76 & 153 & 1,8 & 14 & 0,67 \\
\hline 3 & 63 & 153 & 1,64 & 16 & 0,63 \\
\hline \multicolumn{6}{|l|}{ Etc } \\
\hline 52 & 78 & 153 & 1,82 & 15 & 0,67 \\
\hline Average & 68 & 153 & 1,7 & 14,9 & 0,64 \\
\hline
\end{tabular}
at a Radius $300 \mathrm{~m}$ and $800 \mathrm{~m}$ 
The analysis results of the BSA and BR calculation according to tables 2 and 3 showed that the average BSA of workers was $1.27 \mathrm{~m}^{2}$ and the average workers BR was $0.64 \mathrm{~m}^{3} /$ hour.

C. Hydrogen Sulfide Concentration $\left(\mathrm{H}_{2} \mathrm{~S}\right)$ : The measuring results of $\mathrm{H}_{2}$ Sconcentration in the industrial area showed different results at a radius of $300 \mathrm{~m}$ and $800 \mathrm{~m}$ which was equal to $0.03 \mathrm{mg} /$ $\mathrm{m}^{3}(0.022 \mathrm{ppm})$ and $0.009 \mathrm{mg} / \mathrm{m}^{3}(0.0064 \mathrm{ppm})$

Based on the measurements results, both were above the TLV of $0,0005 \mathrm{ppm}$ according to ATSDR provisions regarding the Odor Limit Value of $\mathrm{H}_{2} \mathrm{~S}$. According to KepMenLH No.KEP-50/ MENLH/1996 regarding the standard level of odor with the TLV of $0.02 \mathrm{ppm}$ then only for the industrial area community at radius $300 \mathrm{~m}$ was above the TLV.

\section{Animal Km and Human Km}

\section{AnimalKm}

Animal Km $=\frac{\text { W Animal }}{\text { BSA Animal }}$

The results of the Animal $\mathrm{Km}$ calculation were shown in table 5, with the average of Animal Km was 5,81.

Table 3: Results of Calculation of Animal Km

\begin{tabular}{|c|c|}
\hline Experimental Animals & Animal Km \\
\hline 1 & 5.814209516 \\
\hline 2 & 5.814209516 \\
\hline 3 & 5.821029467 \\
\hline 4 & 5.821029467 \\
\hline 5 & 5.800520675 \\
\hline 6 & 5.827833234 \\
\hline Average & 5.81 \\
\hline
\end{tabular}

\section{Human Km}

Human $\mathrm{Km}=\frac{\text { W Human }}{\text { BSA Human }}$

Information:

Animal Km: Km factor in animals

Human Km: Km Factors in humans

W: Worker Weight

BSA: Body Surface Area of worker

The results of the Human Km calculation were shown in table 6, with the average of Human $\mathrm{Km}$ was 39.26 .
Table 4: Results of Human Km Calculations in Residential Community Around the Animal Feed and Seafood Processing Industries

\begin{tabular}{|c|c|}
\hline Population & Human KM \\
\hline 1. & 38,46 \\
\hline 2. & 41,53 \\
\hline 3. & 37,72 \\
\hline Etc. & \\
\hline 52. & 41,93 \\
\hline Average & 39,26 \\
\hline
\end{tabular}

E. NOAEL: To determine the safe limit concentration of a chemical begun with the toxicity test determining the highest dose without causing effects on experimental animals or No Observed Adverse Effect Level (NOAEL). ${ }^{(9)}$ Based on US Environmental Protection Agency research stated that $\mathrm{H}_{2} \mathrm{~S}$ NOAEL was $1 \mathrm{mg} / \mathrm{m}^{3}$ or equivalent to $0.0074 \mathrm{mg} / \mathrm{kg}$ obtained from the following calculations.

$$
\begin{aligned}
\mathrm{H}_{2} \mathrm{~S} N O A E L & =1 \mathrm{mg} / \mathrm{m}^{3} \\
& =\frac{1 \times 0,00013 \times 8}{0,1405} \\
& =0,0074 \mathrm{mg} / \mathrm{kg}
\end{aligned}
$$

F. Safe Human Dose: The safe limit for the dose of toxins for humans or Safe Human Dose (SHD) was found to be initiated using the following formula from Shaw et al (2007).

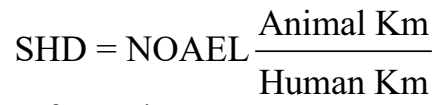

Information:

SHD: Safe Human Dose (mg/kg)

Animal KM: KM factors in animals

Human KM: KM factors in humans

Based on the formula, the calculation obtained from the NOAEL value, the average animal $\mathrm{Km}$, and the average human $\mathrm{Km}$ were:

$$
\mathrm{SHD}=0,0074 \frac{5,81}{39,26}=0,001 \mathrm{mg} / \mathrm{kg}
$$

G. Safe Limits of Hydrogen Sulfide Concentration $\left(\mathbf{H}_{2} \mathbf{S}\right)$ : Determining the safe limits of $\mathrm{H}_{2} \mathrm{~S}$ concentrations used the following formula (William, 1985; Soemirat, 2003; Davis, 1991). 
$\mathrm{C}$ aman $=\frac{(\mathrm{SHD})(\mathrm{W})}{(\delta)(\mathrm{BR})(t)} \mathrm{mg} / \mathrm{m} 3$

To convert units of $\mathrm{mg} / \mathrm{m}^{3}$ to $\mathrm{ppm}$ the following formula was used.(10)

$\mathrm{C}$ aman $=\frac{\# m g / m 3}{(\mathrm{MW})} 24,45 \mathrm{ppm}$

Information:

C safe:The concentration of toxins in the air which is safe for the community $\left(\mathrm{mg} / \mathrm{m}^{3}\right)$

SHD: Safe Human Dose (mg/kg)

W: Weight $(\mathrm{kg})$

$\delta: \%$ of substances absorbed by the lungs

BR: Human respiratory rate $\left(\mathrm{m}^{3} /\right.$ hour $)$

t: Working time (hours)

MW: Molecular Weight

Based on formula above, the calculation of the safe concentration of $\mathrm{H}_{2} \mathrm{~S}$ on average in residential areas around industries at radius $300 \mathrm{~m}$ and $800 \mathrm{~m}$ shown in table 7 and 8 were equal at $0.01 \mathrm{ppm}$.

$$
\begin{aligned}
\text { C safe average } & =\frac{(\mathrm{SHD})(\mathrm{W})}{(\delta)(\mathrm{BR})(t)} \\
& =\frac{(0,0011)(68)}{(50 \%)(0,64)(17)} \\
& =0,0137 \mathrm{mg} / \mathrm{m}^{3} \\
& =0,01 \mathrm{ppm}(\text { radius } 300 \mathrm{~m})
\end{aligned}
$$

C safe average $=\frac{(\mathrm{SHD})(\mathrm{W})}{(\delta)(\mathrm{BR})(t)}$

$$
\begin{aligned}
& =\frac{(0,0011)(68)}{(50 \%)(0,64)(15)} \\
& =0,0155 \mathrm{mg} / \mathrm{m}^{3} \\
& =0,01 \mathrm{ppm} \text { (radius } 800 \mathrm{~m})
\end{aligned}
$$

Table 5: Calculation Results of Safe Concentration in Community Around Medan Industrial Area at Radius 300 m

\begin{tabular}{|c|c|c|c|c|c|c|}
\hline Population & SHD & $\mathbf{W}$ & $\boldsymbol{\delta}$ & BR & t & C safe \\
\hline 1 & 0,0011 & 65 & $50 \%$ & 0,63 & 14 & 0,0161 \\
\hline 2 & 0,0010 & 76 & $50 \%$ & 0,67 & 16 & 0,0144 \\
\hline 3 & 0,0011 & 63 & $50 \%$ & 0,63 & 17 & 0,0132 \\
\hline Etc. & & & & & & \\
\hline
\end{tabular}

Conted...

\begin{tabular}{|c|c|c|c|c|c|c|}
\hline 52 & 0,0010 & 78 & $50 \%$ & 0,67 & 18 & 0,0129 \\
\hline Average & 0,0011 & 68 & $50 \%$ & 0,64 & 16,87 & 0,0137 \\
\hline The lowest C safe & \multicolumn{5}{|c|}{$0,0107 \mathrm{mg} / \mathrm{m} 3$} \\
\hline
\end{tabular}

Based on the calculation of safe concentration in 52 people who were housewives living around the industrial areas of $300 \mathrm{~m}$ radius, the calculationresult of $\mathrm{H}_{2} \mathrm{~S}$ lowest safe concentration or the safest limit for the community was $0.0107 \mathrm{mg} / \mathrm{m}^{3}(0.0077 \mathrm{ppm})$.

$$
\begin{aligned}
\text { The lowest C safe } & =\frac{\# m g / m^{3}}{\mathrm{MW}} \times 24,4 \mathrm{ppm} \\
& =\frac{0,0107}{34,08} \times 24,5 \mathrm{ppm} \\
& =0,0077 \mathrm{ppm}
\end{aligned}
$$

Table 6: Safe Concentration Calculation Results in Community Around Medan Industrial Area at Radius 800 m

\begin{tabular}{|c|c|c|c|c|c|c|}
\hline Population & SHD & W & $\boldsymbol{\delta}$ & BR & T & C safe \\
\hline 1 & 0,0011 & 65 & $50 \%$ & 0,63 & 15 & 0,0150 \\
\hline 2 & 0,0010 & 76 & $50 \%$ & 0,67 & 14 & 0,0165 \\
\hline 3 & 0,0011 & 63 & $50 \%$ & 0,63 & 16 & 0,0140 \\
\hline Etc. & & & & & & \\
\hline 52 & 0,0010 & 78 & $50 \%$ & 0,67 & 15 & 0,0155 \\
\hline Average & 0,0011 & 68 & $50 \%$ & 0,64 & 14,9 & 0,0155 \\
\hline \multicolumn{6}{|c|}{ The lowest C safe } & \multicolumn{6}{|c|}{$0113 \mathrm{mg} / \mathrm{m}^{3}$} \\
\hline
\end{tabular}

Based on the safe concentration calculation in 52 people who were housewives living around the industrial radius of $800 \mathrm{~m}$, the calculation of the lowest safe concentration of $\mathrm{H}_{2} \mathrm{~S}$ or the safest limit for the community was $0.0113 \mathrm{mg} / \mathrm{m} 3(0.0081 \mathrm{ppm})$.

$$
\begin{aligned}
\text { The lowest C safe } & =\frac{\# m g / m^{3}}{\mathrm{MW}} \times 24,5 \mathrm{ppm} \\
& =\frac{0,0113}{34,08} \times 24,5 \mathrm{ppm} \\
& =0,0081 \mathrm{ppm}
\end{aligned}
$$

The calculation results of safe limits at radius $300 \mathrm{~m}$ was of $0.007 \mathrm{ppm}$ and $0.0081 \mathrm{ppm}$ at radius $800 \mathrm{~m}$ could be used to predict the concentration of toxins in the air that was safe if there was no determination of TLV and for comparison with TLV which had been set by various institutions both by the National Standardization Agency, ACGIH, NIOSH and OSHA (William, 1985 in Tualeka, 2013). 


\section{Discussion}

Berdasarkan hasil perhitungan, N OAEL hidrogen sulfida sebesar $1 \mathrm{mg} / \mathrm{m}^{3}$ setara dengan $0,72 \mathrm{ppm}$. Based on the calculation results, $\mathrm{H}_{2} \mathrm{~S}$ NOAEL is $1 \mathrm{mg} /$ $\mathrm{m}^{3}(0.72 \mathrm{ppm})$.Hasil NOAEL ini lebih kecil dari ATSDR tahun 2016 yaitu 2,5 ppm untuk sistem per napasan dengan paparan menengah. This NOAEL result is smaller than ATSDR in 2016, which was 2.5 ppm for respiratory systems with medium exposure.Selain itu besdasarkan NOAEL hasil perhitungan lebih kecil dari penelitian yang dilakukan Brenneman et al (2000) dalam EPA-IRIS NOAEL H2S sebesar $14 \mathrm{mg} / \mathrm{m} 3$ yang menunjukkan bahwa kisaran paparan menengah dengan tingkat keparahan kontinyu. Based on NOAEL, the calculation results are smaller than the research conducted by Brenneman et al (2000) in EPA NOAEL $\mathrm{H}_{2} \mathrm{~S}$ of $14 \mathrm{mg} / \mathrm{m} 3$ which indicates that the range of exposure is medium with continuous severity.(11)

Based on the calculation of the $\mathrm{H}_{2} \mathrm{~S} S H D$ valuehidrogen sulfida didapatkan hasil yaitu $0,001 \mathrm{mg} /$ $\mathrm{kg}$.s obtained at $0.001 \mathrm{mg} / \mathrm{kg}$. HasilSHDini lebih kecil dari penelitian yang dilakukan Brenneman et al (2000) dalam EPA-IRIS (2009) yaitu 0,0044yang menunjukkan bahwa paparan kronis tingkat rendah terhadap $\mathrm{H}_{2} \mathrm{~S}$. Dengan demikian hasil perhitungan nilaiSHDyang dilakukan lebih aman bagi manusia dengan menggunakan NOAEL sebagai perhitungan RfC.The results ofthis SHD are smaller than the research conducted by Brenneman et al (2000) in EPA (2009) which was $0.0044 \mathrm{mg} / \mathrm{kg}$ which indicates the low levels of chronic exposure to $\mathrm{H}_{2} \mathrm{~S}$.(12) Thus the calculation of $S H D$ values performed is safer for humans by using NOAEL as SHD calculation.

Based on the results of this study, the safe concentration of $\mathrm{H}_{2} \mathrm{~S}$ in Medan industrial area is $0.0077 \mathrm{ppm}$ (radius $300 \mathrm{~m}$ ) and $0.0081 \mathrm{ppm}$ (radius 800 $\mathrm{m})$.Hasil penelitian ini lebih lebih kecil dari dari nilai ambang The results of this study are smaller than the $\mathrm{H}_{2} \mathrm{~S}$ TLV concentrationmenurut (ACGIH) yaitu 10 ppm., Badan Standarisasi Nasional Indonesia (SNI 190232-2005) yaitu $10 \mathrm{ppm}$. according to ACGIH which is $10 \mathrm{ppm}$. The Indonesian National Standardization Agency (SNI 19-0232-2005) is 10 ppm.Sedangkan berdasarkan perhitungan konsentrasi aman pada industri pakan ternak dan pengolahan hasil laut lebih besar jika dibanidngkan dengan KepMenLH No.KEP-50/ MENLH/11/1996 nilai ambang $b$ atas yang ditetapkan yaitu 0,02 . If compared with KepMenLH No. KEP-
50/MENLH/11/1996 the TLV odor is set at $0.02 \mathrm{ppm}$. Dengan demikian, nilai hasil penelitian dapat dijadikan acuan dalam menentukan nilai ambang batas hidrogen sulfida $\left(\mathrm{H}_{2} \mathrm{~S}\right)$ di lingkungan pemukiman sekitar industri pakan ternak dan pengolahan hasil laut dan juga aman bagi pekerja yang terpapar $\mathrm{H}_{2} \mathrm{~S}$. The value of research results can be used as a reference in determining the TLV of $\mathrm{H}_{2} \mathrm{~S}$ in residential areas around Medan industries so that it is safe for workers exposed to $\mathrm{H}_{2} \mathrm{~S}$.

\section{Conclusion}

The measurement results of the $\mathrm{H}_{2} \mathrm{~S}$ concentration of inhaled by the public, especially housewives in industrial area at $300 \mathrm{~m}$ radius was $0.03 \mathrm{mg} / \mathrm{m}^{3}(0.022 \mathrm{ppm})$, while the measurement results of $\mathrm{H}_{2} \mathrm{~S}$ concentration at a radius of $800 \mathrm{~m}$ is $0.009 \mathrm{mg} / \mathrm{m} 3(0.0064 \mathrm{ppm})$ which means that both were above the TLV of $0,0005 \mathrm{ppm}$ according to ATSDR provisions regarding the Odor TLV of $\mathrm{H}_{2} \mathrm{~S}$. Whereas according to KepMenLH No.KEP-50/ MENLH/1996 concerning standard level of odor with TLV of $0.02 \mathrm{ppm}$, it was only in the industrial community radius of $300 \mathrm{~m}$ with a concentration of $0.022 \mathrm{ppm}$ which was above the TLV.

Based on manual calculations for the lowest safe concentration limits of $\mathrm{H}_{2} \mathrm{~S}$ was $0.0077 \mathrm{ppm}$ (radius $300 \mathrm{~m}$ ) and $0.0081 \mathrm{ppm}$ (radius $800 \mathrm{~m}$ ). Hal ini jika dibandingkan dengan konsentrasi hidrogen sulfida yang ada di kawasan industri pada radius $300 \mathrm{~m}$ berada di atas batasan konsentrasi aman yaitu 0,022 ppm konsentrasi $\mathrm{H} 2 \mathrm{~S}>0,0077 \mathrm{ppm}$ konsentrasi aman H2S.This was compared to the concentration of $\mathrm{H}_{2} \mathrm{~S}$ at a radius of 300 $\mathrm{m}$ above the safe concentration limit of $0.022 \mathrm{ppm}_{2} \mathrm{~S}$ concentration $>0.0077 \mathrm{ppm} \mathrm{H}_{2} \mathrm{~S}$ safe concentration. Sedangkan untuk kawasan industri radius $800 \mathrm{~m}$ berada di bawah batas konsentrasi aman yang di tentukan yaitu 0,0064 konsentrasi H2S $<0,0081$ ppm konsentrasi aman H2S. Whereas for the radius of $800 \mathrm{~m}$ was below the safe concentration limit, which was determined to

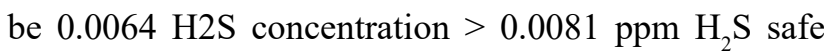
concentration.

\section{Recommendation}

Recommendations for controllers are people at risk of consuming the cytochrome P450 enzymeyang terkandung dalam makanan yang mengandung zat besi seperti kacang-kacangan, sayuran, daging, kuning telur, 
dan ikan untuk menurunkan tingkat hidrogen sulfida dalam tubuh. contained in the iron-containing foods such as beans, vegetables, meat, egg yolks, and fish to lower the $\mathrm{H}_{2} \mathrm{~S}$ levels in the body.Adanya gangguan pada enzim sitokrom oksidase menyebabkan suplai energy hasil oksidasi di mitokondria berkurang, untuk itu perlu mengkonsumsi makanan yang mengandung antioksidan seperti alpukat, delima dan anggur (Tualeka, 2013). The interference with the enzyme cytochrome oxidase causes the supply of energy from oxidation in mitochondria to decrease, so it is necessary to consume foods that contain antioxidants such as avocado, pomegranate and grapes (Tualeka, 2013).

Conflict of Interest: All authors have no conflicts of interest to declare.

Source of Funding: This is an article "Penentuan Konsentrasi Aman Pada Gangguan Kesehatan Masyarakat Akibat Menghirup Udara yang Mengandung Hidrogen Sulfida di Sekitar Kawasan Industri Medan Indonesia" of Occupational Health and Safety Department that was supported by Faculty of Public Health, Airlangga University.

Ethical Clearance: The study was approved by the institutional Ethical Board of the Public Health, North Sumatera.

\section{REFERENCES}

1. Bai, Yong. Bai Q. Sour Corrosion: Hydrogen Sulfide. Subsea Engineering Handbook; 2019.

2. ATSDR. Toxicological Profile for Hydrogen Sulfideand Carbonyl Sulfide. US Department of Health and Human Services; 2016.

3. Cooper, CE. Nicholls P. Sulfide Inhibition of And Metabolism By Cytochorme C Oxidase. Br J Cancer. 2015;
4. Tualeka AR. Toksikologi Industri. Surabaya: Graha Ilmu Mulia; 2013.

5. ACGIH. Threshold Limit Values for Chemical Substances and Physical Agents and Biological Exposure Indices. Cincinnati: American Conference of Governmental Industrial Hygienists; 2014. 1-13 p.

6. Keputusan Menteri Negara Lingkungan Hidup. Baku Tingkat Kebauan. 50 Indonesia; 1996.

7. Nasution D. Analisis Risiko Paparan Hidrogen Sulfida Pada Masyarakat Sekitar Kawasan Industri Medan Di Kecamatan Medan Labuhan Tahun 2016. Universitas Sumatra Utara; 2016.

8. Kristin S. Hydrogen Sulphide Exposure in Waste Water Treatment. J Occup Med Toxicol. 2018;

9. Tualeka AR, Faradisha J, Maharja R. Determination of No-Observed-Adverse-Effect Level Ammonia in White Mice Through CD4 Expression. Dose-Response. 2018;16(4):1-9.

10. Tualeka AR, Wibrata DA, Ahsan A, Rahmawati P, Russeng SS, Wahyu A. Determination of Highest Dose of Ammonia without Effect at Work Environment through the Expression of Interleukin-2 Cell in Rattus Novergicus. 2019;7(6):897-902.

11. US-Environmental Protection Agency. Hydrogen Sulfide. Washington: IRIS; 2009.

12. US-Environmental Protection Agency. User's Guide Biomarkers Data Base. Washington: IRIS; 2009. 